\title{
Transfers of $\mathbf{N}$ metabolites across the ovine liver in response to short-term infusions of an amino acid mixture into the mesenteric vein
}

\author{
G. E. Lobley*, D. M. Bremner, R. Nieto $\dagger$, T. Obitsuł, A. Hotston Moore $\S$ and D. S. Brown \\ Rowett Research Institute, Bucksburn, Aberdeen AB21 9SB, UK
}

(Received 16 January 1998 - Revised 7 April 1998 - Accepted 4 May 1998)

\begin{abstract}
The effect of acute $(4.5 \mathrm{~h})$ infusions into the mesenteric vein of an amino acid (AA) mixture, which simulated the composition of rumen microbial protein, on net transfers of $\mathrm{NH}_{3}$, urea and total AA across the portal-drained viscera (PDV) and liver in the ovine has been examined. Four wether sheep were surgically prepared with vascular catheters across the PDV and liver (Lobley et al. 1995) and were offered a basal diet of $1000 \mathrm{~g}$ grass pellets/d (approximately $1.4 \times$ energy maintenance). Each animal was infused at weekly intervals with one of four dilutions of the AA mixture. These dilutions provided $0 \cdot 44,0 \cdot 88,1 \cdot 32$ and $1 \cdot 84 \mathrm{mmol}$ AA-N/min infused, the lowest of which approximately doubled the net absorption of AA-N from the basal diet. Animals were treated with heparin to allow continuous collection of blood by peristaltic pump for $2 \mathrm{~h}$ preceding, and between $0 \cdot 5-2 \cdot 5$ and $2 \cdot 5-4 \cdot 5 \mathrm{~h}$ after, the start of the AA infusions. Blood flow in the hepatic artery increased (100 v. $208 \mathrm{~g} / \mathrm{min} ; P=0.002)$ in response to AA infusion, while hepatic portal venous flow decreased $(2090$ v. $1854 \mathrm{~g} / \mathrm{min} ; P=0.006)$. The AA infusion also stimulated $\mathrm{O}_{2}$ uptake by the PDV $(P<0.001)$ and liver $(P=0 \cdot 016)$. Absorption across the PDV and hepatic removal of $\mathrm{NH}_{3}$ were unchanged between basal and amino acid infusion conditions. Urea-N removal across the PDV was unaltered, but hepatic production increased $(P<0.001)$ with level of AA infusion. During infusions, net appearance of AA across the PDV was below the theoretical level. This may have been due to inhibition of AA uptake from the small intestine, and/or increased removal by the digestive tract of AA from the systemic circulation associated with greater arterial concentrations. Hepatic extraction of AA increased with level of infusion, both for total AA and those included in the infusate. Total hepatic urea-N production tended towards a maximum (estimated as $2 \mu \mathrm{mol} \mathrm{N} / \mathrm{g}$ liver wet weight per min). The AA removed by the liver and not used for ureagenesis remained similar $(170 \mu \mathrm{mol}$ AA-N/min) between basal and AA infusions. This was presumed available for anabolic purposes (mainly synthesis of export proteins). The proportion of net AA-N appearance (absorption plus infused) across the PDV removed by the liver declined from 0.71 to 0.53 between basal and AA infusions. In contrast to findings from cattle (Wray-Cahen et al. 1997), increased AA infusion did not alter the net removal of glutamine across the liver. This may reflect differences between the studies in $\mathrm{NH}_{3}$ : AA-N absorbed. Further differences between the cattle study and the current findings may relate to the different physiological state (pregnancy $v$. growth), which may alter the partition of AA between anabolic and catabolic fates.
\end{abstract}

Portal-drained viscera: Amino acids: $\mathbf{N}$ metabolites: Plasma protein synthesis

The liver plays a central role in the maintenance of $\mathrm{N}$ homeostasis, and alters both the amount and pattern of absorbed nutrients which become available to the periphery. For example, hepatic removal of $\mathrm{NH}_{3}$, produced primarily across the portal-drained viscera (PDV), alleviates the threat of post-liver vascular hyperammonaemia, which otherwise might result in central nervous system disorders (Summerskill \& Wolpert, 1970). Similarly, absorbed amino acids (AA) are also extracted to varying degrees during transit across the liver, and a proportion of these are utilized for anabolic purposes (net synthesis of constitutive and export proteins). The ability of the liver to provide short-term

\footnotetext{
Abbreviations: AA, amino acids; FA, hepatic artery; FH, hepatic vein; FP, hepatic portal vein; P1, P2, periods $0 \cdot 5-2 \cdot 5$ and $2 \cdot 5-4 \cdot 5$ h of amino acid infusion respectively; PDV, portal-drained viscera.

*Corresponding author: Dr G. E. Lobley, fax +44 (0) 1224 716629, email gel@ rri.sari.ac.uk

$\dagger$ Present address: Consejo Superior de Investigaciones Cientificas, Estacion Experimental del Zaidin, Profesor Albareda 1, 18008 Granada, Spain.

$\$$ Present address: Faculty of Applied Biological Science, Hiroshima University, 1-4-4 Kagamiyama, Higashihiroshima-shi 724, Japan.

§Present address: Department of Clinical Veterinary Science, University of Bristol, Langford, Bristol, UK.
} 
storage of AA, either in free form or protein-bound, offers a potentially important mechanism by which diurnal variations in nutrient supply can be modulated, and provide a more uniform pattern of supply to peripheral tissues during the day. Such net protein synthesis, coupled with the AA which bypass the liver, represent anabolic potential and, when contrasted with catabolism to urea, determines the metabolic efficiency with which absorbed AA are utilized.

Peripheral hyperaminoacidaemia can also cause metabolic side effects (Kuhara et al. 1991) and, under conditions when both $\mathrm{NH}_{3}$ (Lobley \& Milano, 1997) and AA (WrayCahen et al. 1997) inflows to the liver exceed the capacity for disposal of $\mathrm{N}$ as urea, priorities have to be assigned as to which metabolites are removed. In cattle subjected to shortterm overloads of AA supply by infusion into the mesenteric vein, the main hepatic priority appeared to be removal of $\mathrm{NH}_{3}$ (Wray-Cahen et al. 1997). Furthermore, the fractional extraction of both individual and total absorbed AA by the liver was maintained at a constant rate, such that expansion of hepatic free amino acid and/or protein pools (both constitutive and export) must have occurred. Finally, increased AA supply led to elevated removal of glutamine by the liver, which is in agreement with the concept in nonruminants that, under conditions of a relative excess of AA, ornithine cycle flux is maintained by intra-mitochondrial generation of $\mathrm{NH}_{3}$ from glutamine (Meijer et al. 1985; Häussinger et al. 1992).

The cattle studied by Wray-Cahen et al. (1997) were postlactation pregnant cows which may have requirements for AA to support replenishment of muscle, and other peripheral tissues mobilized during milk production, as well as development of the fetus. Thus, such transfers may not be typical of growing and fattening animals, where both AA supply and protein gain are lower. For these reasons it was decided to examine if, in maturing young sheep with limited capacity for protein deposition, similar qualitative and quantitative responses to acute elevation of AA supply occurred compared with those in cattle. Were this to be the case, then relatively simple and universal equations could be incorporated into models which predict AA availability to peripheral tissues in farm species (see Hanigan et al. 1997).

\section{Materials and methods}

\section{Animals and diet}

Four Suffolk-cross wether sheep (12-15 months old, initial live weight $35-42 \mathrm{~kg}$ ) were prepared with indwelling silicone rubber catheters in the aorta plus mesenteric, hepatic portal (FP) and hepatic (FH) veins as described previously (Lobley et al. 1995). After 3 weeks recovery, during which time the animals were adjusted to grass pellets $(1000 \mathrm{~g} / \mathrm{d}$ as fed; $10.5 \mathrm{MJ}$ metabolizable energy $/ \mathrm{kg} \mathrm{DM} ; 22.5 \mathrm{~g} \mathrm{~N} / \mathrm{kg}$ DM; DM $950 \mathrm{~g} / \mathrm{kg}$ ), they were placed in metabolism cages with the feed supplied as twenty-four $1 \mathrm{~h}$ portions by means of automated feeders.

\section{Experimental design}

Measurements were performed on each animal on four separate occasions at weekly intervals. On experimental days, animals were infused via the mesenteric vein catheter, first with sterile $0.15 \mathrm{M}-\mathrm{NaCl}$ for $4 \mathrm{~h}$, followed by $4.5 \mathrm{~h}$ of an AA mixture at one of four dilutions detailed later (see p. 372). All animals received each of the four dilutions in a design based initially on a $4 \times 4$ Latin square.

A mixture of L-AA (Ajinomoto Co. Inc., Tokyo, Japan), which was based on the composition of rumen microbial protein (Storm \& Ørskov, 1983), was prepared as a stock solution in $0.05 \mathrm{M}$-sodium phosphate and $0.10 \mathrm{M}-\mathrm{NaCl}$ solution to the following concentrations (mM): alanine 104 , arginine 37 , glycine 91 , histidine 15 , isoleucine 55 , leucine 75 , lysine 73 , methionine 22 , phenylalanine 44 , proline 44, serine 55, threonine 58, tryptophan 11 , valine 60. Tyrosine and cysteine were omitted on grounds of solubility and stability respectively. Aspartate, asparagine, glutamate and glutamine were excluded because exchanges of glutamine and asparagine in response to the amino acid load were to be determined, and part of any metabolic response would include the conversion of these amides to the respective dicarboxylic acids.

The four infusates were prepared as follows: the stock solution alone or diluted in proportions $1: 3,1: 1$ or $3: 1$ with $0 \cdot 15 \mathrm{M}-\mathrm{NaCl}$. All solutions were adjusted to $\mathrm{pH} 7 \cdot 4$ and then filtered through a $0 \cdot 22 \mu \mathrm{m}$ filter under aseptic conditions, followed by autoclaving. Sterilized solutions were stored at $4^{\circ}$ until used.

On each experimental day, the animals were infused with two solutions: (1) $0 \cdot 15 \mathrm{M}$-sodium $p$-aminohippurate, containing $10^{5} \mathrm{IU}$ of sodium heparin $/ \mathrm{l}$, at $40 \mathrm{~g} / \mathrm{h}$ for $8.5 \mathrm{~h}$; (2) either $0 \cdot 15 \mathrm{M}-\mathrm{NaCl}$ (first $4 \mathrm{~h}$ ) or the appropriate AA solution (next $4.5 \mathrm{~h}$ ), at a rate of $120 \mathrm{~g} / \mathrm{h}$. Each solution was supplied from a separate pump, but combined by means of a mixing valve before infusion into the mesenteric vein catheter. The average rates of AA-N infusion for the four solutions were $0 \cdot 44,0 \cdot 88,1.33$ and $1.84 \mathrm{mmol} / \mathrm{min}$.

Blood was withdrawn continuously for $2 \mathrm{~h}$ intervals over the last $6.5 \mathrm{~h}$ of infusion at a rate of $6 \mathrm{~g} / \mathrm{h}$ using a multichannel peristaltic pump, and collected over ice as described previously (Lobley et al. 1995). The sample collected over the first $0.5 \mathrm{~h}$ of AA infusion was used for determination of water in plasma and blood. The first $2 \mathrm{~h}$ of collection (during $0 \cdot 15 \mathrm{M}-\mathrm{NaCl}$ infusion) was designated as 'basal', while the periods $0 \cdot 5-2 \cdot 5$ and $2 \cdot 5-4 \cdot 5 \mathrm{~h}$ of AA infusion were designated P1 and P2 respectively. Plasma was prepared by centrifugation at $1000 \mathrm{~g}$ for $15 \mathrm{~min}$ at $4^{\circ}$.

During infusions any unusual behaviour or food refusals were recorded, as was body temperature at appropriate intervals.

\section{Analyses}

All gravimetric additions detailed were to four decimal places. Blood gas analyses were determined on an ABL3 Blood Gas Analyzer (Radiometer, Copenhagen, Denmark) and packed cell volume by haematocrit. Plasma flow $(\mathrm{g} / \mathrm{min})$ was quantified by downstream dilution of sodium $p$-aminohippurate using the gravimetric approach (Lobley et al. 1995). $\mathrm{NH}_{3}$ was measured in fresh plasma only by the glutamate dehydrogenase $(E C$ 1.4.1.2) procedure using a Kone Dynamic selective Analyzer (Kone Instruments, Espoo, Finland), although on a few occasions a related 
manual procedure needed to be adopted. Urea concentrations $(\mathrm{mmol} / \mathrm{kg})$ were determined in both plasma and blood by isotope dilution. To a known weight $(0 \cdot 3 \mathrm{~g})$ of fresh plasma or blood was added a known weight $(0 \cdot 3 \mathrm{~g})$ of $3 \mathrm{mM}-$ $\left[{ }^{15} \mathrm{~N}_{2}\right]$ urea (99 atom \%; Mass Trass Inc., Woburn, MA, USA). The sample was mixed and stored at $-20^{\circ}$ until analysed. The sample was subsequently deproteinized, the $t$ butyldimethylsilyl derivative prepared (Calder \& Smith, 1988) and analysed by GC-mass spectrometry in the electron-impact mode with fragment ions of $\mathrm{m} / \mathrm{z} 231$ and 233 monitored. Appropriate standards were prepared to ensure the linearity of the procedure. The precision of this approach is approximately $1 \%$, two and four times superior to the diacetyloxime and urease (EC 3.5.1.5)-glutamate dehydrogenase techniques respectively (Milano, 1997). Water contents were obtained by freeze-drying known weights of plasma or blood (the latter haemolysed by a $1: 1(\mathrm{v} / \mathrm{v})$ addition of water).

Free AA were measured by adding $0 \cdot 2 \mathrm{~g}$ cold $\left(4^{\circ}\right) 1 \mathrm{mM}-$ L-norleucine to $1 \mathrm{~g}$ plasma (or $1 \mathrm{~g}$ blood plus $1 \mathrm{~g}$ cold $0.2 \mathrm{mM}$-L-norleucine) and storing the mixture in Eppendorf tubes at $-80^{\circ}$. Immediately before AA analysis, the sample was thawed on ice, remixed and $0 \cdot 15 \mathrm{ml}$ sulphosalicylic acid $(480 \mathrm{~g} / \mathrm{l})$ added, followed by mixing and centrifugation at $10000 \mathrm{~g}$ for $5 \mathrm{~min}$. The supernatant fraction was then clarified through $0 \cdot 2 \mu \mathrm{m}$ microcentrifuge filters (Spin-X; Sigma Chemical Co., Poole, Dorset), the filtrate adjusted to approximately $\mathrm{pH} 2-3(\mathrm{pH}$ paper) with $\mathrm{NaOH}$ and the sample analysed on an LKB Alpha Plus Amino Acid Analyzer (LKB Pharmacia, Uppsala, Sweden), using lithium citrate buffer combinations appropriate for physiological fluids. Individual, as opposed to total, AA transfers will be reported in a separate publication, except for glutamine and asparagine.

\section{Calculations}

Blood flow was calculated from plasma flow/(1-packed cell volume). Hepatic artery (FA) flow (blood or plasma) was calculated as the difference between flow in the FH and FP. Mass transfers across the PDV and liver were calculated respectively as:

$$
=\left[\mathrm{C}_{\mathrm{p}}-\mathrm{C}_{\mathrm{a}}\right] \times \mathrm{FP},
$$

and

$$
=\left[\mathrm{C}_{\mathrm{h}}\right] \mathrm{FH}-\left[\mathrm{C}_{\mathrm{p}}\right] \times \mathrm{FP}-\left[\mathrm{C}_{\mathrm{a}}\right] \mathrm{FA},
$$

where $C_{a}, C_{p}, C_{h}$ are metabolite concentrations in arterial, FP and FH fluids respectively.

For $\mathrm{NH}_{3}$ transfers, concentrations in plasma were taken as equal to that in blood (Milano, 1997). Urea concentrations were calculated for plasma and blood water.

\section{Statistics}

The original design was based on a Latin square, but one infusion on each of three sheep needed to be repeated for technical reasons, and these were performed as a fifth infusion at the end. In consequence, the data were first analysed, with the basal data excluded, as a split-plot design with animals treated as blocks, infusion level as whole plots and period as subplot. In all comparisons, the effect of period was found to be not significant. In subsequent analyses, AA infusion level and sample site were treated as whole plots and subplots respectively, with level $\times$ site interactions also considered. Data were also tested for linear or quadratic trends. For specific comparisons, data during the basal $(\mathrm{NaCl})$ infusion were analysed separately and then basal $v . \mathrm{P} 1$ or $\mathrm{P} 2$ and $\mathrm{P} 1 v$. P2 compared by general ANOVA with sheep $\times$ level as a block and period as treatment.

Comparisons of metabolite concentrations in blood $v$. plasma, or blood water $v$. plasma water, were analysed by one-way ANOVA with each sample treated as a block. All analyses were performed using Genstat 3.2 for Windows Release 3.2 (Lawes Agricultural Trust, Rothamsted, UK).

\section{Results}

All animals completed the trial satisfactorily. Immediately following the start of the AA infusion slight shivering and increased respiration rate were sometimes observed. For this reason, during the first $0 \cdot 5 \mathrm{~h}$ of these infusions blood was collected only for DM determinations of vascular fluids. Within this period the animals apparently returned to normal. Overall, there was a tendency throughout the study for body temperatures to be elevated by approximately $0 \cdot 5^{\circ}$ during the AA infusion, but returned to normal 2-3 h later. At the highest level of infusion two of the animals refused feed and showed elevated temperature $\left(+1 \cdot 0-1 \cdot 5^{\circ}\right.$ above pre-infusion records). When these infusions were repeated at the end of the series no intake or temperature problems were observed. The other repeat infusion related to abnormal FP blood flows, which was suspected to relate to the catheter tip becoming positioned in a side branch. When repeated at the end of the series, the measured blood flows were similar to those of the other infusion periods.

FA flow contributed $5-10 \%$ of total liver flow, in agreement with previous observations (Lobley et al. 1995; Table 1). The AA infusion caused a significant increase in FA flow $(P=0.002)$, particularly during the last $2 \mathrm{~h}(\mathrm{P} 2)$. There was a corresponding decline in both FP $(P=0 \cdot 006)$ and $\mathrm{FH}(P=0.080)$ flows of approximately $10 \%$.

$\mathrm{O}_{2}$ consumptions were significantly lower $(P<0.001$; Table 1) across the PDV compared with the liver during both basal and AA infusion periods, which is contrary to previous observations (Lobley et al. 1995, 1996). Infusion of AA resulted in significant increases in $\mathrm{O}_{2}$ uptake across both the PDV $(P<0.001)$ and liver $(P=0.016)$. Linear regression analysis between hepatic urea release $(\mathrm{mmol} /$ $\mathrm{min}$ ) and $\mathrm{O}_{2}$ consumption $(\mathrm{mmol} / \mathrm{min})$ by the liver yielded a significant $(P=0.028)$ relationship:

$$
\begin{aligned}
& \mathrm{O}_{2} \text { consumption }=-1.972(\operatorname{SE} 0 \cdot 864) \text { urea release } \\
& -1 \cdot 780 \text { (SE 0.453). }
\end{aligned}
$$

\section{Ammonia and urea-nitrogen transfers across splanchnic} tissues

For all periods and treatments, there was net appearance of $\mathrm{NH}_{3}$ across the PDV and net removal by the liver (Table 2). 
Table 1. Effect of level of infusion of an amino acid mixture on blood flow and oxygen exchanges across the portal-drained viscera (PDV) and liver of young sheep fed on a basal ration of grass pellets $(1000 \mathrm{~g} / \mathrm{d})^{*}$

\begin{tabular}{|c|c|c|c|c|c|c|c|}
\hline & \multicolumn{4}{|c|}{ Amino acid infusion } & \multicolumn{3}{|c|}{ Statistical significance§: $P$} \\
\hline \multicolumn{8}{|l|}{ Blood flow (g/min) } \\
\hline Hepatic portal vein & 2090 & 1853 & 1854 & $76 \cdot 1$ & 0.006 & NS & 0.038 \\
\hline Hepatic vein & 2190 & 2004 & 2061 & $80 \cdot 6$ & 0.080 & NS & 0.092 \\
\hline
\end{tabular}

$\mathrm{P} 1, \mathrm{P} 2$, periods of amino acid infusion $0.5-2 \cdot 5 \mathrm{~h}$ and $2 \cdot 5-4.5 \mathrm{~h}$.

${ }^{*}$ For details of animals and procedures, see pp. 372-373.

† First $2 \mathrm{~h}$ of collection during infusion of $0.15 \mathrm{M}-\mathrm{NaCl}$.

$\ddagger$ Based on ANOVA, with animals as blocks; 24 residual df.

$\S$ The SED values are for period comparisons.

II Calculated as the difference between hepatic and hepatic portal venous flows.

In all cases $(P<0.001)$, removal by the liver exceeded net appearance of $\mathrm{NH}_{3}$ across the PDV, the additional extraction involved $\mathrm{NH}_{3}$ produced by peripheral tissues. In consequence, concentrations of $\mathrm{NH}_{3}$ in $\mathrm{FH}$ plasma were lower than in FA plasma ( $P<0.001$; values not shown). $\mathrm{NH}_{3}$ appearance across the PDV was similar for most of the basal periods, although the value was significantly lower before the $1.84 \mathrm{mmol} / \mathrm{min}$ infusion compared with the $0.88 \mathrm{mmol} / \mathrm{min}$ infusion (338 v. $497 \mu \mathrm{mol} \mathrm{NH}_{3} / \mathrm{min}$, SED $42.9, P=0.029)$. There was a similar trend $(P=0.076)$ between the same periods in the absolute, but not proportional, magnitude of hepatic $\mathrm{NH}_{3}$ extraction. The reasons for this effect during these basal periods are unclear.

Neither $\mathrm{NH}_{3}$ PDV appearance nor liver uptake were significantly different during AA infusions compared with basal periods. During the $\mathrm{P} 2$ collections $\mathrm{PDV} \mathrm{NH}$ appearance was lower during the $0.44 \mathrm{mmol} \mathrm{N} / \mathrm{min}$ infusion compared with the $0.88 \mathrm{mmol} \mathrm{N} / \mathrm{min}$ infusion (321 v. $504 \mu \mathrm{mol} / \mathrm{min}$, SED 52.7, $P=0 \cdot 044)$; again no explanation for this was immediately obvious. There were no differences in hepatic removal of $\mathrm{NH}_{3}$ either as a result of the level of AA infusion or between infusion periods $\mathrm{P} 1$ and $\mathrm{P} 2$.

Urea concentrations in blood water were slightly, but significantly, greater than in plasma water $(5 \cdot 297$ v. 5·210, SED $0.007, P<0.001)$. Urea transfer data presented are calculated based on blood water urea concentrations and blood water flows (Table 2). Net removal of urea by the PDV occurred for all samples and levels. There were no significant differences between PDV removal during the pre-AA infusion periods and, during these times, 0.5 of the urea released across the liver entered the digestive tract. This urea-N entry into the digestive tract was equivalent to 0.77 of $\mathrm{NH}_{3}$ appearance across the PDV. Level of amino acid infusion had no effect on net transfers of urea into the digestive tract.

For all periods, net appearance of urea was observed across the liver. During pre-infusion periods, $0 \cdot 72$ of hepatic urea- $\mathrm{N}$ appearance could be accounted for by $\mathrm{NH}_{3}$ extraction. Urea production by the liver increased between basal and both periods $\mathrm{P} 1$ and $\mathrm{P} 2$ of AA infusion $(P<0 \cdot 001)$ and linearly with level of AA infusion $(P<0.001)$. However, there were no significant differences between periods P1 and $\mathrm{P} 2$ of infusion.

\section{Amino acid transfers}

Under basal conditions, there was net uptake of total AA-N across the PDV, the magnitude of which was unaffected by AA infusions $7 \mathrm{~d}$ previously. The PDV appearance of total AA increased linearly $(P<0.001)$ with level of infusion (Table 3 ) but two interesting features were observed. First, net appearance (i.e. infused plus absorbed) was significantly lower $(P=0 \cdot 012)$ during the infusion period $P 2$. Second, the apparent recovery of infused AA, calculated as: net PDV appearance/(infused AA + basal AA absorption), declined as the level of infusion increased, such that at the $1.84 \mathrm{mmol}$ AA-N/min rate the average value was only $0.75-0.79$ of that expected.

Under basal conditions, extraction of total AA by the liver was 0.71 of net PDV appearance. This proportion decreased $(\mathrm{P}=0.069)$ for $\mathrm{P} 1(0.49)$ and $\mathrm{P} 2(0.59)$ during the AA infusions, but with no level $\times$ period interactions. When only those AA contained within the infusate are considered, the difference in proportional removal by the liver of the PDV net appearance was more marked $(P=0.013)$ between basal $(0 \cdot 70)$ and $\mathrm{P} 1(0.44)$ and $\mathrm{P} 2(0.55)$, again with no level $\times$ period interactions.

The derived fates of net $\mathrm{N}$ transfers across the liver are shown in Fig. 1. The difference between urea-N production and hepatic $\mathrm{NH}_{3}$ removal was ascribed to AA-N used for ureagenesis. Net 'retention' values (i.e. AA-N used for anabolic purposes) were computed as the difference between measured net $\mathrm{N}$ uptakes (total AA-N plus $\mathrm{NH}_{3}$ ) and outputs (urea-N only). These hepatic net 'retentions' were not significantly different between any levels of AA infusion or between periods $\mathrm{P} 1$ and $\mathrm{P} 2$; for example, during AA infusions the values averaged $176 \mu \mathrm{mol} \mathrm{N} / \mathrm{min}$, which was not significantly different from the basal periods (172 $\mu \mathrm{mol} \mathrm{N/min).}$

\section{Asparagine and glutamine transfers}

Values for asparagine and glutamine transfers were 
Table 2. Effect of level of infusion of an amino acid mixture on transfers of blood ammonia and urea-nitrogen across the portal-drained viscera (PDV) and liver of sheep fed on a basal ration of grass pellets $(1000 \mathrm{~g} / \mathrm{d})^{*}$

\begin{tabular}{|c|c|c|c|c|c|c|c|c|c|c|}
\hline & & \multicolumn{5}{|c|}{ Amino acid infusion (mmol N/min) } & \multicolumn{4}{|c|}{ Statistical significanceł: $P$} \\
\hline \multicolumn{11}{|c|}{$\mathrm{NH}_{3}(\mu \mathrm{mol} / \mathrm{min})$} \\
\hline \multirow[b]{2}{*}{ Liver: } & $\mathrm{P} 2$ & & 321 & 504 & 425 & 410 & 0.044 & NS & NS & NS \\
\hline & $\mathrm{P} 1$ & & -518 & -515 & -508 & -522 & NS & NS & NS & NS \\
\hline \multicolumn{11}{|c|}{ Urea-N ( $\mu \mathrm{mol} / \mathrm{min})$} \\
\hline PDV: & $\mathrm{P} 1$ & & -506 & -274 & -332 & -290 & NS & \multirow[b]{2}{*}{ NS } & \multirow[b]{2}{*}{ NS } & \multirow[b]{2}{*}{ NS } \\
\hline \multirow{3}{*}{ Liver: } & $\mathrm{P} 2$ & -332 & -200 & -416 & -348 & -524 & NS & & & \\
\hline & $\mathrm{P} 1$ & & 932 & 1030 & 1078 & 1246 & 0.038 & \multirow[b]{2}{*}{$<0.001$} & \multirow[b]{2}{*}{$<0.001$} & \multirow[b]{2}{*}{ NS } \\
\hline & P2 & 698 & 800 & 1018 & 1198 & 1226 & $<0.001$ & & & \\
\hline
\end{tabular}

$\mathrm{P} 1, \mathrm{P} 2$, periods of amino acid infusion $0.5-2 \cdot 5 \mathrm{~h}$ and $2 \cdot 5-4 \cdot 5 \mathrm{~h}$.

* For details of animals and procedures, see pp. 372-373.

† First $2 \mathrm{~h}$ of collection during infusion of $0.15 \mathrm{M}-\mathrm{NaCl}$

¥By ANOVA (see p. 373) with animals treated as blocks. For comparisons of level, data for B were excluded and the effect of level and sample were included in the treatment; residual df 21 . For comparisons between pairs of periods the analysis included animal $\times$ level as blocks with period as the treatment; residual df 15 . All analyses were repeated with tests for linear and quadratic features.

calculated based on both plasma and blood samples. Similar results were obtained from both analyses, but values are presented only for blood to be consistent with total AA values (Table 4). Previous treatments did not affect the basal transfers of either glutamine or asparagine. There was net appearance of asparagine across the PDV for all treatments, but this declined as the level of AA infusion increased $(P=0.044)$ and was lower during period P2 than P1 $(P<0.003)$. PDV appearance of glutamine also declined with both the level of AA infusion and the period of sampling, but neither effect was significant. Tyrosine, which was also excluded from the infusate, showed a linear decline in apparent net absorption $(P<0.001)$ as infusion of AA was increased (values not shown).

Both asparagine and glutamine exhibited net removal by the liver. Hepatic glutamine extraction was significantly greater during AA infusions than the basal periods $(-33 \cdot 3$ v. $-17 \cdot 4 \mu \mathrm{mol} / \mathrm{min}, P=0 \cdot 015)$ but there were no linear trends nor was there a difference between P1 and P2. During both the basal and AA infusion periods, hepatic extraction of glutamine exceeded PDV appearance, indicative of additional removal from peripheral sources. For

Table 3. Effect of level of infusion of an amino acid mixture on transfers of total and infused amino acid-nitrogen across the portal-drained viscera (PDV) and liver of sheep fed a basal ration of grass pellets $(1000 \mathrm{~g} / \mathrm{d}) *$

\begin{tabular}{|c|c|c|c|c|c|c|c|c|c|c|}
\hline & & \multicolumn{5}{|c|}{ Amino acid infusion (mmol N/min) } & \multicolumn{4}{|c|}{ Statistical significance $\neq: P$} \\
\hline & & Basal $(\mathrm{B}) \dagger$ & 0.44 & $0 \cdot 88$ & $1 \cdot 32$ & $1 \cdot 84$ & Level & $\mathrm{B} v . \mathrm{P} 1$ & $\mathrm{~B} v . \mathrm{P} 2$ & $\mathrm{P} 1$ v. P2 \\
\hline \multicolumn{11}{|c|}{$\begin{array}{l}\text { Total amino acid-N } \\
(\mu \mathrm{mol} / \mathrm{min})\end{array}$} \\
\hline PDV: & $\mathrm{P} 1$ & & 1120 & 1270 & 1476 & 1989 & 0.030 & \multirow[b]{2}{*}{$<0.001$} & \multirow[b]{2}{*}{0.001} & \multirow[b]{2}{*}{0.010} \\
\hline \multirow{2}{*}{ Liver: } & $\begin{array}{l}\mathrm{P} 2 \\
\mathrm{P} 1\end{array}$ & 518 & $\begin{array}{r}842 \\
-545\end{array}$ & $\begin{array}{l}1033 \\
-583\end{array}$ & $\begin{array}{l}1346 \\
-857\end{array}$ & $\begin{array}{r}1394 \\
-938\end{array}$ & $\begin{array}{c}0.092 \\
\text { NS }\end{array}$ & & & \\
\hline & $\mathrm{P} 2$ & -366 & -533 & -598 & -758 & -823 & NS & 0.002 & 0.023 & NS \\
\hline \multicolumn{11}{|c|}{$\begin{array}{l}\text { Infused amino acid-N } \\
(\mu \mathrm{mol} / \mathrm{min})\end{array}$} \\
\hline PDV: & $\mathrm{P} 1$ & 427 & 960 & 1191 & 1426 & 1913 & 0.007 & \multirow[t]{2}{*}{$<0.001$} & \multirow[t]{2}{*}{$<0.001$} & \multirow[t]{2}{*}{0.012} \\
\hline \multirow{2}{*}{ Liver: } & $\begin{array}{l}\mathrm{P} 2 \\
\mathrm{P} 1\end{array}$ & & $\begin{array}{r}715 \\
-415\end{array}$ & $\begin{array}{r}969 \\
-510\end{array}$ & $\begin{array}{l}1343 \\
-735\end{array}$ & $\begin{array}{l}1421 \\
-689\end{array}$ & $\begin{array}{c}0.023 \\
\text { NS }\end{array}$ & & & \\
\hline & $\mathrm{P} 2$ & -294 & -468 & -517 & -689 & -758 & NS & $<0.002$ & 0.009 & NS \\
\hline
\end{tabular}

$\mathrm{P} 1, \mathrm{P} 2$, periods of amino acid infusion $0.5-2.5 \mathrm{~h}$ and $2.5-4.5 \mathrm{~h}$.

* For details of animals and procedures, see pp. 372-373.

$\dagger$ First $2 \mathrm{~h}$ of collection during infusion of $0.15 \mathrm{M}-\mathrm{NaCl}$.

¥ By ANOVA (see p. 373) with animals treated as blocks. For comparisons of level, data for B were excluded and the effect of level and sample were included in the treatment; residual df 21 . For comparisons between pairs of periods the analysis included animal $\times$ level as blocks with period as the treatment; residual df 15 . All analyses were repeated with tests for linear and quadratic features. 


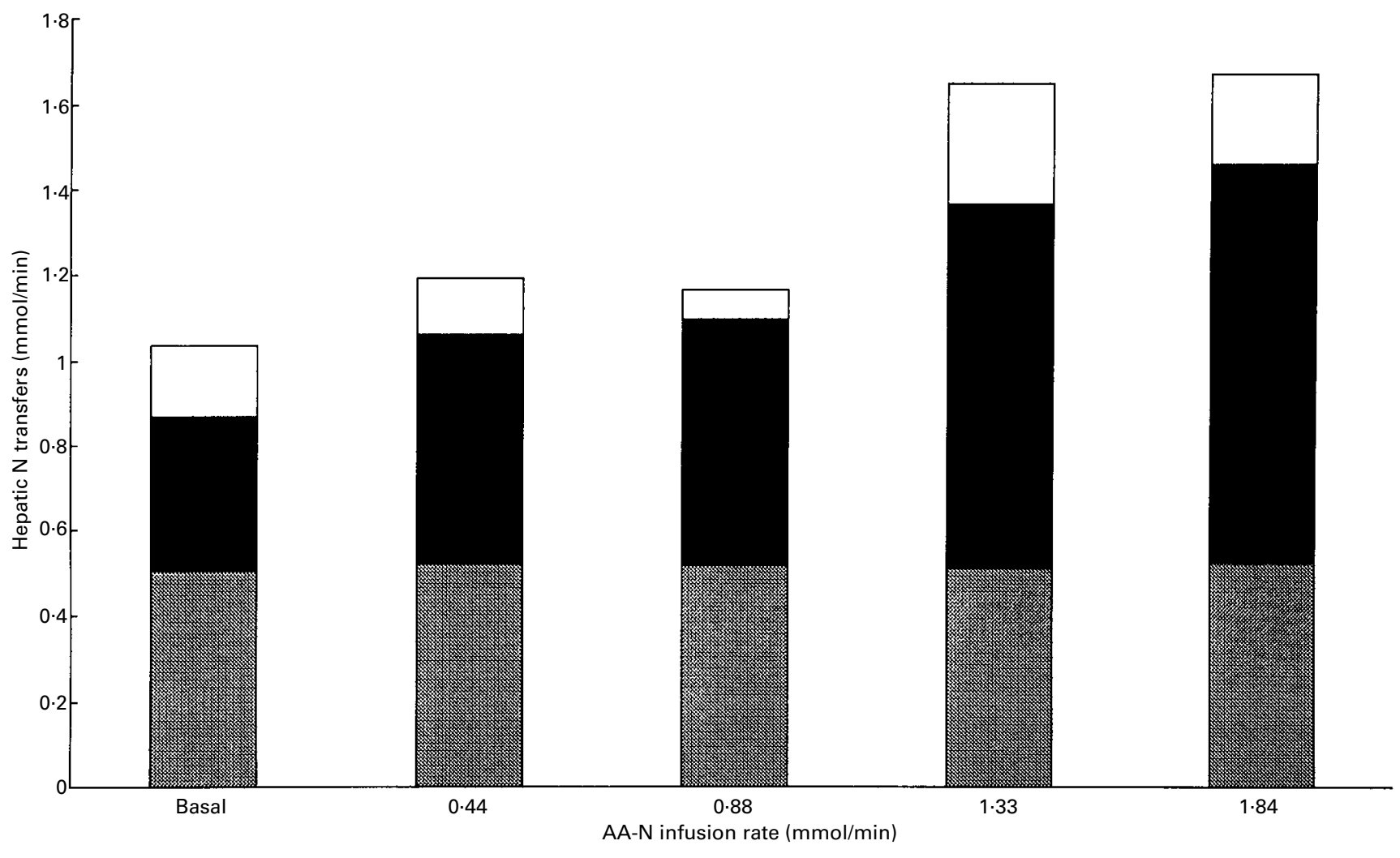

Fig. 1. Transfers of $\mathrm{N}$ compounds ( $\mathrm{mmol} / \mathrm{min}$ ) across the ovine liver in response to increasing levels of amino acid-nitrogen (AA-N) infusion for $2 \mathrm{~h}$

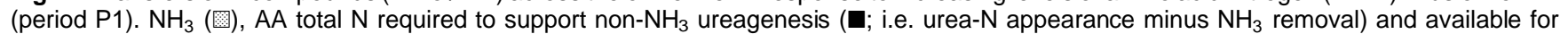
hepatic anabolic purposes ( $\square$; i.e. total AA-N removal minus AA-N to urea). For details of animals and procedures, see pp. $372-373$.

Table 4. Effect of level of infusion of an amino acid mixture on transfers of blood glutamine and asparagine across the portal-drained viscera (PDV) and liver of sheep fed on a basal ration of grass pellets $(1000 \mathrm{~g} / \mathrm{d}) *$

\begin{tabular}{|c|c|c|c|c|c|c|c|c|c|c|}
\hline & & \multicolumn{5}{|c|}{ Amino acid infusion (mmol N/min) } & \multicolumn{4}{|c|}{ Statistical significance $\neq: P$} \\
\hline \multicolumn{11}{|c|}{ Glutamine $(\mu \mathrm{mol} / \mathrm{min})$} \\
\hline & P2 & $6 \cdot 1$ & $13 \cdot 4$ & $3 \cdot 2$ & 3.9 & 0.8 & NS & NS & NS & NS \\
\hline Llver: & $\mathrm{P} 1$ & $-17 \cdot 4$ & $-31 \cdot 3$ & $-27 \cdot 2$ & $-42 \cdot 9$ & $-41 \cdot 4$ & NS & 0.010 & NS & NS \\
\hline \multicolumn{11}{|c|}{ Asparagine $(\mu \mathrm{mol} / \mathrm{min})$} \\
\hline PDV: & $\mathrm{P} 1$ & \multirow[b]{2}{*}{$48 \cdot 3$} & $63 \cdot 8$ & $35 \cdot 5$ & 23.9 & $24 \cdot 7$ & NS & \multirow[b]{2}{*}{ NS } & \multirow[b]{2}{*}{$<0.001$} & \multirow[b]{2}{*}{0.003} \\
\hline & $\mathrm{P} 2$ & & 43.4 & 27.9 & $8 \cdot 0$ & $1 \cdot 4$ & 0.044 & & & \\
\hline Liver: & $\mathrm{P} 1$ & & $-32 \cdot 7$ & $-20 \cdot 2$ & $-25 \cdot 6$ & -31.9 & NS & \multirow[b]{2}{*}{ NS } & \multirow[b]{2}{*}{0.029} & \multirow[b]{2}{*}{0.019} \\
\hline & P2 & $-28 \cdot 8$ & -24.9 & $-19 \cdot 2$ & $-8 \cdot 4$ & $-9 \cdot 1$ & NS & & & \\
\hline
\end{tabular}

$\mathrm{P} 1, \mathrm{P} 2$, periods of amino acid infusion $0 \cdot 5-2 \cdot 5 \mathrm{~h}$ and $2 \cdot 5-4.5 \mathrm{~h}$.

${ }^{*}$ For details of animals and procedures, see pp. 372-373.

†First $2 \mathrm{~h}$ of collection infusion of $0 \cdot 15 \mathrm{M}-\mathrm{NaCl}$.

$¥$ By ANOVA (see p. 373) with animals treated as blocks. For comparisons of level, data for B were excluded and the effect of level and sample were included in the treatment; residual df 21 . For comparisons between pairs of periods the analysis included animal $\times$ level as blocks with period as the treatment; residual df 15 . All analyses were repeated with tests for linear and quadratic features. 
hepatic asparagine removal, there was also no linear trend with level of AA infusion, but it was lower during P2 compared with either basal or P1 periods $(P=0.017)$. Overall, liver extraction of asparagine was equal to or less than net absorption.

\section{Discussion}

The infusate was prepared to match the composition of rumen microbial protein and thus reflect the pattern observed on the basal diet (see Lobley et al. 1996), rather than use a commercial infusate with a composition atypical of that absorbed by ruminants on natural forages (WrayCahen et al. 1997). The rates of infusion amounted to increases of one, two, three and four times the basal absorption of these AA and, at the upper rates, must be considered non-physiological. This was deliberate, however, in order to examine what limitations, if any, existed on the rates of $\mathrm{N}$ transfers and ureagenesis across the liver. In the bovine (Wray-Cahen et al. 1997), blood flows were insensitive to AA infusion but, in the current study, there were small but significant responses, with the increase in FA input partly compensating for the reduced flow from the digestive tract. Whether the latter reflects a response against the induced arterial hyperaminoacidaemia and provides a mechanism to lower absorption and reduce the peripheral signals is unknown. While, from these findings, it would appear that AA play a less important role in the regulation of splanchnic blood flow than does metabolizable energy intake (Lindsay, 1993), a different response may have been obtained if the infusate was supplied enterally rather than parenterally.

\section{Portal-drained viscera transfers}

Under basal conditions, $\mathrm{NH}_{3}$ contributed $0 \cdot 45$ of $\mathrm{NH}_{3}$ plus total AA-N appearance in FP blood, values similar to those reported for animals offered roughage-based rations (for example, see Reynolds et al. 1991; Lobley et al. 1996; Goetsch et al. 1997). Although urea-N disappearance across the PDV could account for 0.77 of $\mathrm{NH}_{3}$ appearance, values from animals on a similar ration would indicate that only 0.35 of this $\mathrm{N}$ was returned to hepatic urea (Sarraseca et al. 1998). This suggests that perhaps three-quarters of the $\mathrm{NH}_{3}$ absorbed was released directly from diet sources and that two-thirds of the urea- $\mathrm{N}$ which entered the digestive tract was destined for anabolic purposes, mainly synthesis of rumen microbial protein.

At the beginning of the study it was not known what effect the acute AA infusions would exert on the metabolism of the basal diet. $\mathrm{NH}_{3}$ uptake was unaltered, even during the slight inappetence observed for two sheep at the highest level of infusion, suggesting that bacterial fermentations of both ruminal and caecal origin continued unchecked. In contrast, recovery of AA-N across the PDV was less than expected from the numerical sum of basal appearance plus infusate, with the missing proportion greatest at the highest rate of administration. Furthermore, the recoveries were significantly lower during the sampling period P2 compared with P1. Two possible biological reasons for this latter observation might be considered, although both relate to changes in 'net' appearance across the small intestine. First, either the rate of passage of digesta through the small intestine and/or nutrient absorption may have been reduced. Second, greater extraction of AA by the PDV tissues may have occurred as the systemic supply (arterial concentration $\times$ blood flow) increased, and MacRae et al. (1997) have demonstrated that, in sheep, approximately $80 \%$ of the AA used to support PDV protein synthesis arise from arterial rather than luminal sources. In consequence, net 'basal' PDV appearance, which is the difference between absorption from the lumen and extraction from the arterial inflow, would not be constant and might decline as the AA infusions into the mesenteric vein increased. Consideration of possible changes in net appearance can be gleaned from transfers of non-infused AA. Asparagine appearance across the PDV, for example, declined with rate of AA infusion and between periods $\mathrm{P} 1$ and P2. A similar effect was observed with glutamine and tyrosine. Subject to the proviso that changes in digestive tract metabolism of these three AA had not occurred, these observations suggest that net absorption may indeed have been inhibited in proportion to infusion level.

\section{Hepatic exchanges}

Under basal conditions $\mathrm{NH}_{3}$ removal was 0.72 of urea-N appearance, a higher proportion than that observed in previous studies on similar diets (Lobley et al. 1995, 1996). A proportion greater than 0.5 means that some of the $\mathrm{NH}_{3}-\mathrm{N}$ is converted, via glutamate dehydrogenase and aspartate:oxoglutarate aminotransferase (EC 2.6.1.1), to aspartate and enters the ornithine cycle through the arginosuccinate synthetase ( $E C$ 6.3.4.5) reaction in order to balance $\mathrm{N}$ inflows for urea synthesis. The removal of AA$\mathrm{N}$ was more than adequate to account for the remaining $0 \cdot 28$ of urea-N.

Hepatic urea-N production by the liver appears to be maximal at approximately $2 \mu \mathrm{mol} / \mathrm{g}$ per min (for example, see Symonds et al. 1981; Orzechowski et al. 1987; Lobley \& Milano, 1997) and, based on a liver mass of $16-19 \mathrm{~g} / \mathrm{kg}$ live weight (Lobley et al. 1994), these animals could produce approximately $1.2-1.4 \mathrm{mmol}$ urea-N/min. This is similar to the values observed at the higher levels of AA infusion, and thus maximal stimulation of ureagenesis has probably occurred. Under the experimental conditions, inflows to the liver of AA-N exceeded $\mathrm{NH}_{3}$ by up to 27:1 on an absolute basis (concentrations $\times$ vascular inflows) and 4.5:1 on a net (absorption) basis. Despite this excess of AA availability, there was no change in the removal of $\mathrm{NH}_{3}$ which, therefore, must have remained a preferred source of glutamate-N (and thus ultimately aspartate-N) for the first two levels of infusion.

Although it may seem obvious for animals fed above maintenance intake that inflowing $\mathrm{N}$ substrates must equal, or exceed, urea-N output, this has not always been a universal finding. For example, in some studies with wellfed cattle (for example, see Reynolds et al. 1991; WrayCahen et al. 1997) lower $\mathrm{N}$ (i.e. $\mathrm{NH}_{3}$ plus $\mathrm{AA}-\mathrm{N}$ ) removal than urea-N output across the liver has been reported. This is all the more serious when the requirements for production of hepatic export proteins are considered. In fed sheep these 
can amount to between $0 \cdot 17$ and $0 \cdot 40$ of total liver synthesis, the equivalent of 0.05-0.42 of extracted AA-N (Connell et al. 1997; Lobley \& Milano, 1997). The difference between extracted AA- $\mathrm{N}$ and that required to complete non- $\mathrm{NH}_{3}$ urea synthesis was assumed equal to that available for anabolic purposes and, at $176 \mu \mathrm{mol} \mathrm{N} / \mathrm{min}$, on the basal diet was equivalent to $22 \mathrm{~g}$ protein/d. This value is close to the maximum rate of hepatic export protein synthesis determined in fed sheep (20 g/d; Connell et al. 1997). As the sheep in the current study were still growing and fed above maintenance there will also be a small increase in liver protein mass. Why such balances have not been achieved in other studies is unclear, but reliance on the simpler (and cheaper) $\alpha$-amino-N technique may be an important factor. The summation of individual AA used in the current study does increase the variance, but provides a better index of concentration changes. In addition, the use of continuous blood collections also improves the overall reliability of the data and dampens the effect of short-term fluctuations in metabolic transfers. All these considerations assume that AA are only available to the liver in free form, but it is also possible that peptides and proteins may undergo hepatic extraction and provide alternative sources of AA.

Overall, therefore, the absolute quantity of AA extracted by the liver during basal and infusion conditions was enough to furnish $\mathrm{N}$ for the extra ureagenesis and to provide sufficient to maintain export protein synthesis within normal limits (see Fig. 1). This contrasts with companion studies in pregnant non-lactating cows where total uptake of AA was in excess of these requirements and necessitated speculation that either expansion of the hepatic free AA pools had occurred, or that constitutive and/or export protein net anabolism was stimulated (Wray-Cahen et al. 1997). The reasons for these differences are unclear, but the physiological state of the cows, recovery from lactation plus the metabolic demands of the fetus, may have required restoration and production of larger protein reserves, either as tissue mass or the mobile plasma protein pool.

The cattle study also showed an increasing and approximately linear removal of glutamine by the liver in response to increasing levels of AA infusion (Wray-Cahen et al. 1997). This did not occur in the current study, albeit that there was an increase associated with AA infusions in general. Glutamine extracted by the liver performs several roles (Häussinger et al. 1992; Lobley \& Milano, 1997), one of which is to provide a source of $\mathrm{NH}_{3}$, through the action of mitochondrial glutaminase ( $E C$ 3.5.1.2) to maintain flux through the regulatory enzyme, carbamoyl phosphate synthetase 1 (EC 6.3.4.16; Meijer et al. 1985), and this mechanism is of particular importance in non-ruminant metabolism (Häussinger et al. 1992). In ruminants under normal dietary regimens, $\mathrm{NH}_{3}$ supply is usually in excess of AA-N catabolism, and the requirement for additional $\mathrm{NH}_{3}$ sources, therefore, is redundant. This is seen at the lower two infusion rates of AA, where net $\mathrm{NH}_{3}$ uptake accounted for 0.5 or more of urea- $\mathrm{N}$ production. At the highest rate of AA infusion, however, only $42-45 \%$ of urea synthesis could be accommodated by direct $\mathrm{NH}_{3}$ uptake and, if it is assumed that $\mathrm{N}$ flow through carbomoyl phosphate synthetase 1 must equal $50 \%$ of urea- $\mathrm{N}$ production, then up to 60

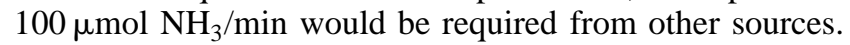

This is within the range of hepatic glutamine removal, provided that both the amido- and amino- $\mathrm{N}$ were available, although glutaminase would only liberate the former. Alternatively, the resultant shortfall could be met if amido-N from extracted glutamine plus asparagine were utilized. In the case of the cattle study, at the higher rates of infusion $\mathrm{NH}_{3}-\mathrm{N}$ extraction:urea- $\mathrm{N}$ release decreased to between 0.33 and $0 \cdot 39$, with the additional extraction of glutamine providing sufficient amide- $\mathrm{N}$ to adjust combined $\mathrm{NH}_{3}$ supply back to approximately $50 \%$ of urea-N release (Wray-Cahen et al. 1997). These observations in cattle and sheep provide support in vivo for the role of amide AA in provision of additional $\mathrm{NH}_{3}$ under conditions of high $\mathrm{AA}$ and low $\mathrm{NH}_{3}$ supply to ruminants.

Overall, these findings indicate that, even under conditions of excess AA supply, hepatic removal of $\mathrm{NH}_{3}$ absorbed from the digestive tract is given a higher metabolic priority than prevention of peripheral hyperaminoacidaemia. Removal of excess AA by the liver appears, in the short-term, to be constrained by the limits of non- $\mathrm{NH}_{3}-$ derived ureagenesis and the requirements for export protein synthesis. This is true, at least, for sheep with limited wholebody net anabolic capacity, and appears to contrast with findings obtained from pregnant cattle, where demands of both the conceptus and peripheral tissue replenishment may be considerable. Furthermore, constraints on net utilization may have been introduced by the omission of certain AA (notably cysteine and tyrosine) from the infusate. If either of these AA became 'limiting' beyond the limits of direct supply and synthesis de novo, then this could divert other AA from anabolic to catabolic (ureagenic) fates. In addition, the findings reported here relate to total AA transfers, and it is important to determine whether there are priorities as to which individual AA are extracted by the liver and enter the ornithine cycle.

\section{Acknowledgements}

This work was funded by the Scottish Office Agriculture, Environment and Fisheries Department as part of the Core budget to the Rowett Research Institute. R. Nieto was a recipient of a grant from Consejo Superior de Investigaciones Cientificus (Spain) while T. Obitsu was supported by a fellowship for Research at a Centre of Excellence Abroad through the Japanese Society for the Promotion of Science.

\section{References}

Calder AG \& Smith A (1988) Stable isotope ratio analysis of leucine and ketoisocaproic acid in blood plasma by gas chromatography/mass spectrometry. Rapid Communications in Mass Spectrometry 2, 14-16.

Connell A, Calder AG, Anderson SE \& Lobley GE (1997) Hepatic protein synthesis in the sheep: effect of intake as monitored by use of stable-isotope-labelled glycine, leucine and phenylalanine. British Journal of Nutrition 77, 255-271.

Goetsch AL, Patil AR, Galloway DL, Kouakou B, Wang ZS, Park KK \& Rossi JE (1997) Net flux of nutrients across splanchnic tissues in wethers consuming grasses of different sources and physical forms ad libitum. British Journal of Nutrition 77, 769781.

Hanigan MD, Dijkstra J, Gerrits WJJ \& France J (1997) Modelling 
post-absorptive protein and amino acid metabolism in the ruminant. Proceedings of the Nutrition Society 56, 631-643.

Häussinger D, Lamers WH \& Moorman AFM (1992) Hepatocyte heterogeneity in the metabolism of amino acids and ammonia. Enzyme 46, 72-93.

Kuhara T, Ikeda S, Ohneda A \& Sasaki Y (1991) Effects of intravenous infusion of 17 amino acids on the secretion of $\mathrm{GH}$, glucagon and insulin in sheep. American Journal of Physiology 260, E21-E26.

Lindsay DB (1993) Metabolism of the portal-drained viscera. In Quantitative Aspects of Ruminant Digestion and Metabolism, pp. 267-289 [JM Forbes and J France, editors]. Wallingford, Oxon: CAB International.

Lobley GE, Connell A, Lomax MA, Brown DS, Milne E, Calder AG \& Farningham DAH (1995) Hepatic detoxification of ammonia in the ovine liver; possible consequences for amino acid catabolism. British Journal of Nutrition 73, 667-685.

Lobley GE, Connell A, Milne E, Newman AM \& Ewing AT (1994) Protein synthesis in splanchnic tissues of sheep offered two levels of intake. British Journal of Nutrition 71, 3-12.

Lobley GE \& Milano GD (1997) Regulation of hepatic nitrogen metabolism in ruminants. Proceedings of the Nutrition Society 56, 547-563.

Lobley GE, Weijs PJM, Connell A, Calder AG, Brown DS \& Milne E (1996) The fate of absorbed and exogenous ammonia as influenced by forage or forage-concentrate diets in growing sheep. British Journal of Nutrition 76, 231-248.

MacRae JC, Bruce LA, Brown DS \& Calder AG (1997) Amino acid use by the gastrointestinal tract of sheep given lucerne forage. American Journal of Physiology 273, G1158-G1165.
Meijer AJ, Lof C, Ramos IC \& Verhoeven AJ (1985) Control of ureagenesis. European Journal of Biochemistry 148, 189196.

Milano GD (1997) Liver nitrogen transactions in sheep (Ovis aries). $\mathrm{PhD}$ Thesis, University of Aberdeen.

Orzechowski A, Motyl T, Pierzynowski G \& Barej W (1987) Hepatic capacity for ammonia removal in sheep. Journal of Veterinary Medicine 34A, 108-112.

Reynolds CK, Tyrrell HF \& Reynolds PJ (1991) Effects of diet forage-to-concentrate ratio and intake on energy metabolism in growing beef heifers: net nutrient metabolism by visceral tissues. Journal of Nutrition 121, 1004-1015.

Sarraseca A, Milne E, Metcalf MJ \& Lobley GE (1998) Urea recycling in sheep: effect of intake. British Journal of Nutrition 79, 79-88.

Storm E \& Ørskov ER (1983) The nutritive value of rumen microorganisms in ruminants. 1. Large-scale isolation and chemical composition of rumen micro-organisms. British Journal of Nutrition 50, 463-470.

Summerskill WHJ \& Wolpert E (1970) Ammonia metabolism in the gut. American Journal of Clinical Nutrition 23, 633639.

Symonds H, Denise W, Mather L \& Collins KA (1981) The maximum capacity of the bovine liver to metabolize ammonia. Proceedings of the Nutrition Society 40, 63A.

Wray-Cahen D, Roberts S, Metcalf JA, Backwell FRC, Bequette BJ, Brown DS, Sutton JD \& Lobley GE (1997) Hepatic response to increased exogenous supply of plasma amino acids by infusion into the mesenteric vein of Holstein-Friesian cows in late gestation. British Journal of Nutrition 78, 913-930. 